\begin{tabular}{|c|c|c|}
\hline 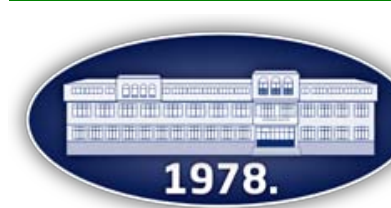 & Publisher: Faculty of Agronomy Čačak & 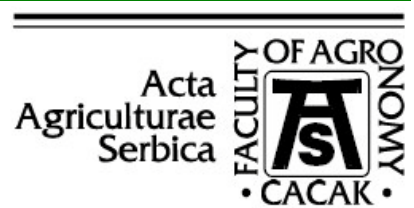 \\
\hline & www.afc.kg.ac.rs & \\
\hline
\end{tabular}

\title{
Growth and yield performance of late-season plum cultivars in the Belgrade area
}

\author{
Dragan Milatović1 ${ }^{*}$, Gordan Zec ${ }^{1}$, Dejan Đurović ${ }^{1}$, Đorđe Boškov ${ }^{1}$ \\ 1 Department of Fruit Growing, Faculty of Agriculture, University of Belgrade, Nemanjina 6, 11080 Belgrade - Zemun, \\ Serbia \\ *Corresponding author: mdragan@agrif.bg.ac.rs
}

Received 20 April 2020; Accepted 10 May 2020

\begin{abstract}
A B S T R A C T
Characteristics of growth and cropping (trunk cross-sectional area, yield per tree, yield efficiency, biennial bearing index, and fruit weight) were studied in 25 late-season plum cultivars in the Belgrade area during the eight-year period (2012-2019). The cultivar 'Stanley' was used as a control for comparison. The period of study was divided into initial bearing (age of trees: four and five years) and full bearing (age of trees: between six and eleven years). Significant differences in yield among cultivars were found in both initial and full bearing periods. The average yield per tree in the period of initial bearing ranged from $1.6 \mathrm{~kg}$ in 'Pozna Plava' to $10.9 \mathrm{~kg}$ in 'Topper', and from $12.3 \mathrm{~kg}$ in 'Pozna Plava' to $26.1 \mathrm{~kg}$ in 'Mildora' in the period of full bearing. Compared with the control cultivar, significantly lower yields in the full bearing period were obtained in eight cultivars, while higher vigour, expressed as trunk cross-sectional area (TCSA), was found in ten cultivars. Cumulative yield efficiency varied between $0.46 \mathrm{~kg} / \mathrm{cm}^{2}$ in 'Požegača' and $1.90 \mathrm{~kg} / \mathrm{cm}^{2}$ in 'Topper'. Biennial bearing index was the lowest (0.06) in 'Nada', and the highest (0.90) in 'Tophit'. Fruit weight ranged from $17.9 \mathrm{~g}$ in 'Požegača' to $57.0 \mathrm{~g}$ in 'Empress'. Compared with the control, fruit weight was significantly higher in seven cultivars, and significantly lower in nine cultivars. On the basis of high yields and large fruit size, the cultivars 'Bluefre', 'Empress', 'Jojo', 'Nada', 'President' and 'Tophit' can be recommended for growing in the Belgrade region.
\end{abstract}

Keywords: Prunus domestica, cropping, trunk cross-sectional area, yield efficiency, biennial bearing index, fruit weight.

\section{И 3 В $о$ Д}

Карактеристике раста и родности (површина попречног пресека дебла, принос по стаблу, коефицијент родности, индекс алтернативне родности и маса плода) проучаване су код 25 сорти шљиве позног времена зрења на подручју Београда у периоду од осам година (2012-2019). Као стандард за поређење је узета сорта Стенли. Период испитивања је подељен на почетну родност (старост стабала четири и пет година) и пуну родност (старост стабала 6-11 година). Утврђене су значајне разлике у приносу између проучаваних сорти, како у периоду почетне, тако и у периоду пуне родности. Просечан принос по стаблу у периоду почетне родности је варирао од 1,6 kg (Позна плава) до 10,9 kg по стаблу (Топер), а у периоду пуне родности од 12,3 kg (Позна плава) до 26,1 kg (Милдора). У поређењу са стандард сортом, статистички значајно нижи принос у периоду пуне родности имало је осам сорти, док је већу бујност, изражену преко површине попречног пресека дебла, имало десет сорти. Маса плода је била у распону од 17,9 g (Пожегача) до 57,0 g (Емпрес). У односу на контролу, седам сорти је имало значајно већу, а девет сорти значајно мању масу плода. На основу високе родности и велике крупноће плода, за гајење у београдском подручју се могу препоручити сорте Блуфри, Емпрес, Јојо, Нада, Президент и Топхит.

Кључне речи: Prunus domestica, принос, површина попречног пресека дебла, коефицијент родности, индекс алтернативне родности, маса плода.

\section{Introduction}

In Serbia, plum is, along with apple, the most commonly cultivated fruit crop. The average annual production in the period 2017-2019 was 439,904 t (Statistical Office of the Republic of Serbia, 2020). Most of the fruit produced (more than $70 \%$ ) is processed into plum brandy, while smaller quantities are used for drying or processing into jam, marmalade, and other products. A relatively small amount of fruits is used for fresh consumption. The export of fresh plum fruits has increased in the last 10-15 years, especially to Russia. The most widely grown plum cultivars in Serbia are 'Stanley', 'Čačanska Rodna', and 'Čačanska Lepotica', while 'Čačanska Rana', 'Čačanska Najbolja, 'Valjevka',
'President', 'Empress' ('Grossa di Felisio') and others are much less common (Milatović, 2019).

When choosing cultivars of fruit trees for growing, one of the most important characteristics is their productivity. The yield of plum cultivars varies greatly by year, depending on meteorological factors, such as temperatures during flowering, and rainfall during the growing season. Therefore, objective data on cultivar productivity can only be obtained from a long-term study. Studies of the cropping of plum cultivars over many years have been carried out in various European countries, such as the Czech Republic (Blažek et al., 2004; Kosina, 2004; Blažek and Pišteková, 2012), Norway (Meland, 2010), Romania (Vişanu et al., 2012), Poland (Markuszewski and Kopytowski, 2013; 
Glowacka and Rozpara, 2017), Hungary (Mészáros et al., 2015) and Serbia (Glišić et al., 2016a; Glišić et al., 2016b; Miletić et al., 2019).

The aim of this paper was to study the productivity of a number of plum cultivars of late ripening time in the Belgrade area over an eight-year period. The results obtained will be useful for the selection of cultivars for growing or for their use in further breeding.

\section{Materials and methods}

The research was carried out in the plum collection orchard of the Faculty of Agriculture in Belgrade, at the Radmilovac Experimental Farm , over a period of eight years (2012-2019). The orchard was planted in 2009, and trees were 4-11 years old during the study period. The trial included 25 late-maturing cultivars of the European plum (Prunus domestica L.).'Stanley' was used as a control cultivar for comparison. All cultivars were grafted on Myrobalan (Prunus cerasifera Ehrh.) seedling rootstock, and each was represented by five trees in the orchard. The training form was a pyramidal crown, and the planting distance was $4.5 \times 3 \mathrm{~m}$. In the experimental orchard, standard cultural practices were applied, without irrigation.

Trunk cross-sectional area (TCSA) was calculated based on trunk circumference measured at a height of $30 \mathrm{~cm}$ above the graft union. Cumulative yield efficiency (CYE) was calculated as the ratio of the cumulative yield over eight years (2012-2019) to the TCSA in the last year of the study (2019), and is expressed in $\mathrm{kg}$ per $\mathrm{cm}^{2}$. The biennial bearing index was calculated using the formula given by Monselise and Goldschmidt (1982):

$$
B B I=\frac{1}{n-1} \times\left[\frac{\left|a_{2}-a_{1}\right|}{\left|a_{2}+a_{1}\right|}+\frac{\left|a_{3}-a_{2}\right|}{\left|a_{3}+a_{2}\right|}+\cdots+\frac{\left|a_{n}-a_{n-1}\right|}{\left|a_{n}+a_{n-1}\right|}\right]
$$

where: $\mathrm{BBI}=$ biennial bearing index; $\mathrm{n}=$ number of experimental years; $\mathrm{a}_{1}, \mathrm{a}_{2}, \ldots, \mathrm{a}_{\mathrm{n}}=$ yield in the $1^{\text {st }}, 2^{\text {nd }}, \ldots$ , $\mathrm{n}^{\text {th }}$ year.

The period of study is divided into initial bearing (tree age: four and five years) and full bearing (tree age: $6-11$ years). Fruit weight was determined on a sample of 25 fruits per cultivar.

The obtained data were statistically analysed using the analysis of variance. Significance of differences between mean values was determined using Duncan's multiple range test at the 0.05 level of probability.

\section{Results and discussion}

Significant yield differences were found between the studied cultivars, both in the initial and full bearing periods (Table 1).

The average yield per tree in the initial bearing period varied from $1.6 \mathrm{~kg}$ in 'Pozna Plava' to $10.9 \mathrm{~kg}$ per tree in 'Topper'. The standard cultivar, 'Stanley', was characterised by early start of bearing, and high initial yields. This was also the case with the cultivars
'Elena', 'Empress', 'Jojo', 'Lorida', 'Tardicotes', 'Top', and 'Topper'. In contrast, 'Pozna Plava', 'Zlatka' and 'Anna Späth' were characterised by late entry into bearing and low initial yields.

The average yield per tree at full bearing ranged from $12.3 \mathrm{~kg}$ in 'Pozna Plava' to $26.1 \mathrm{~kg}$ in 'Mildora'. The highest yields, which were at the level of the standard cultivar ('Stanley'), were obtained by the cultivars 'Mildora', 'Tophit', 'Jojo', 'Nada', 'Lorida', 'Vengerka Krupnaya Sladkaya', 'Topking', 'President', 'Bluefre', 'Strinava', 'Elena', 'Tardicotes', 'Verity', 'Topper', and 'Empress'. Compared with the standard cultivar, statistically significantly lower yields were obtained in seven cultivars ('Pozna Plava', 'Vengerka Pozdnaya', 'Požegača', 'Anna Späth', 'Charadzeyka', 'Zlatka', and 'Top').

Across years, the highest yield was recorded in 2019 (27.4 kg per tree on average for all cultivars). The lowest yield was obtained in 2017 (17.3 kg per tree on average). During the research period, in the experimental orchard, neither strong winter frosts nor late spring frosts that could lead to freezing of plum generative organs were observed. The lower yield obtained in some years in some cultivars can be explained by the tendency for alternate cropping, i.e. high yield (over-cropping) in the previous year.

The average yield per hectare for all cultivars in the full bearing period was $15.1 \mathrm{t}$, with variation among cultivars between $9.1 \mathrm{t}$ and $19.3 \mathrm{t}$. The data obtained are in accordance with the literature data for European plum cultivars grafted on Myrobalan seedling rootstock. Vitanova et al. (2004), in Bulgaria, for an eight-year period, reported an average yield of 10.2$19.8 \mathrm{t} / \mathrm{ha}$ for six plum cultivars, while Vişanu et al. (2012), in the conditions of Romania, for eight plum cultivars, for a ten-year period, obtained an average yield of 10.0-23.3 t/ha.

High yields of the cultivars 'Tophit', 'Jojo', 'Empress', and 'President' in this study are in line with the results obtained by Blažek and Pišteková (2009). Also, our results confirm the reports of Ogašanović et al. (2005) on the high productivity of 'Mildora'.

The vigour of the tested cultivars, expressed as trunk cross-sectional area (TCSA), was the lowest in 'Topper' $\left(73.1 \mathrm{~cm}^{2}\right)$ and the highest in 'Požegača' (178.4 $\mathrm{cm}^{2}$ ) (Table 2). The standard cultivar, 'Stanley', is a moderately vigorous cultivar (Milatović, 2019). Compared with the control, statistically significantly higher TCSA values were obtained in ten cultivars, while none had statistically significantly lower TCSA values.

Blažek and Pišteková (2009) reported that cultivar 'Tophit' had almost twice higher TCSA compared with 'Topper', which was confirmed in our study. The results on lower vigour of 'Empress' and 'Čačanska Rodna' are in agreement with the results reported by Blažek et al. (2004). 
Table 1

Yield (kg per tree) of plum cultivars in the periods of initial and full bearing

\begin{tabular}{|c|c|c|c|c|c|c|c|c|c|c|}
\hline \multirow{2}{*}{ Cultivar } & \multicolumn{3}{|c|}{ Initial bearing } & \multicolumn{7}{|c|}{ Full bearing } \\
\hline & 2012 & 2013 & Average & 2014 & 2015 & 2016 & 2017 & 2018 & 2019 & Average \\
\hline Anna Späth & 0.1 & 3.7 & $1.9 \mathrm{f}$ & 14.5 & 25.1 & 6.3 & 6.8 & 9.6 & 31.0 & $15.6 \mathrm{de}$ \\
\hline Bluefre & 3.6 & 12.5 & $8.1 \mathrm{ab}$ & 17.5 & 28.1 & 23.5 & 16.7 & 14.9 & 37.7 & $23.1 \mathrm{a}-\mathrm{c}$ \\
\hline Čačanska Rodna & 4.3 & 8.5 & $6.4 \mathrm{~b}-\mathrm{d}$ & 15.6 & 21.6 & 22.6 & 11.6 & 10.2 & 27.9 & $18.2 \mathrm{~b}-\mathrm{e}$ \\
\hline Charadzeyka & 0.2 & 6.1 & 3.2 ef & 3.7 & 23.2 & 15.4 & 11.5 & 13.7 & 25.8 & $15.6 \mathrm{de}$ \\
\hline Elena & 5.6 & 14.7 & $10.2 \mathrm{a}$ & 24.7 & 15.7 & 27.1 & 18.6 & 25.9 & 16.9 & $21.5 \mathrm{a}-\mathrm{c}$ \\
\hline Empress & 4.5 & 15.6 & $10.1 \mathrm{a}$ & 18.8 & 30.4 & 3.3 & 17.6 & 21.6 & 23.5 & 19.2 a-e \\
\hline Jojo & 4.8 & 15.4 & $10.1 \mathrm{a}$ & 27.5 & 20.0 & 28.2 & 14.6 & 10.3 & 52.9 & $25.6 \mathrm{a}$ \\
\hline Lorida & 5.1 & 16.2 & $10.7 \mathrm{a}$ & 24.6 & 29.0 & 23.2 & 24.6 & 30.8 & 21.1 & $25.5 \mathrm{a}$ \\
\hline Mildora & 1.2 & 12.3 & $6.8 \mathrm{bc}$ & 23.5 & 5.3 & 30.6 & 40.8 & 25.4 & 30.8 & $26.1 \mathrm{a}$ \\
\hline Nada & 3.3 & 5.9 & $4.6 \mathrm{c}-\mathrm{f}$ & 26.5 & 23.4 & 21.8 & 22.7 & 27.7 & 31.7 & $25.6 \mathrm{a}$ \\
\hline Narach & 3.4 & 7.8 & $5.6 \mathrm{~b}-\mathrm{e}$ & 21.6 & 16.4 & 2.5 & 21.7 & 23.0 & 21.8 & $17.8 \mathrm{~b}-\mathrm{e}$ \\
\hline Požegača & 0.2 & 6.8 & $3.5 \mathrm{~d}-\mathrm{f}$ & 7.0 & 17.5 & 6.3 & 15.2 & 8.1 & 21.5 & $12.6 \mathrm{e}$ \\
\hline Pozna Plava & 0.1 & 3.1 & $1.6 \mathrm{f}$ & 15.8 & 11.4 & 10.1 & 10.4 & 8.1 & 17.8 & $12.3 \mathrm{e}$ \\
\hline President & 2.0 & 5.4 & $3.7 \mathrm{~d}-\mathrm{f}$ & 16.2 & 21.2 & 27.2 & 8.4 & 25.2 & 41.3 & $23.2 \mathrm{ab}$ \\
\hline Stanley & 4.3 & 16.1 & $10.2 \mathrm{a}$ & 15.0 & 28.5 & 30.7 & 25.1 & 16.1 & 29.0 & $24.1 \mathrm{ab}$ \\
\hline Strinava & 1.8 & 8.5 & $5.2 \mathrm{~b}-\mathrm{e}$ & 16.3 & 8.7 & 28.7 & 16.5 & 36.3 & 23.1 & $21.6 \mathrm{a}-\mathrm{c}$ \\
\hline Tardicotes & 5.1 & 16.3 & $10.7 \mathrm{a}$ & 21.4 & 21.3 & 23.3 & 15.4 & 22.1 & 22.3 & $21.0 \mathrm{a}-\mathrm{c}$ \\
\hline Top & 7.6 & 13.1 & $10.4 \mathrm{a}$ & 18.5 & 24.7 & 11.6 & 17.9 & 5.9 & 23.5 & $17.0 \mathrm{c}-\mathrm{e}$ \\
\hline Topper & 9.2 & 12.6 & $10.9 \mathrm{a}$ & 20.6 & 20.3 & 30.4 & 12.4 & 20.2 & 13.6 & $19.6 \mathrm{a}-\mathrm{d}$ \\
\hline Tophit & 2.4 & 3.0 & $2.7 \mathrm{ef}$ & 1.6 & 46.8 & 0.1 & 37.1 & 6.0 & 64.4 & $26.0 \mathrm{a}$ \\
\hline Topking & 3.5 & 9.2 & $6.3 \mathrm{~b}-\mathrm{d}$ & 31.8 & 12.8 & 45.5 & 18.7 & 27.2 & 8.9 & $24.1 \mathrm{ab}$ \\
\hline V. K. Sladkaya & 4.5 & 6.3 & $5.4 \mathrm{~b}-\mathrm{e}$ & 28.5 & 7.4 & 37.7 & 14.4 & 26.3 & 34.0 & $24.7 \mathrm{a}$ \\
\hline V. Pozdnaya & 0.2 & 7.0 & $3.6 \mathrm{~d}-\mathrm{f}$ & 19.4 & 0.3 & 16.4 & 10.3 & 12.7 & 15.5 & $12.4 \mathrm{e}$ \\
\hline Verity & 1.0 & 12.8 & $6.9 \mathrm{bc}$ & 25.9 & 8.8 & 40.3 & 5.8 & 19.4 & 20.5 & $20.1 \mathrm{a}-\mathrm{c}$ \\
\hline Zlatka & 0.6 & 2.7 & $1.7 \mathrm{f}$ & 10.4 & 11.2 & 19.3 & 17.9 & 12.5 & 27.5 & $16.5 \mathrm{c}-\mathrm{d}$ \\
\hline Average & 3.1 & 9.7 & 6.4 & 18.7 & 19.2 & 21.3 & 17.3 & 18.4 & 27.4 & 20.4 \\
\hline
\end{tabular}

Mean values followed by the same letter within a column do not differ significantly according to Duncan's multiple range test at $\mathrm{P} \leq 0.05$.

High yields of the cultivars 'Tophit', 'Jojo', 'Empress', and 'President' in this study are in line with the results obtained by Blažek and Pišteková (2009). Also, our results confirm the reports of Ogašanović et al. (2005) on the high productivity of 'Mildora'.

The vigour of the tested cultivars, expressed as trunk cross-sectional area (TCSA), was the lowest in 'Topper' $\left(73.1 \mathrm{~cm}^{2}\right)$ and the highest in 'Požegača' (178.4 $\mathrm{cm}^{2}$ ) (Table 2). The standard cultivar, 'Stanley', is a moderately vigorous cultivar (Milatović, 2019). Compared with the control, statistically significantly higher TCSA values were obtained in ten cultivars, while none had statistically significantly lower TCSA values.

Blažek and Pišteková (2009) reported that cultivar 'Tophit' had almost twice higher TCSA compared with 'Topper', which was confirmed in our study. The results on lower vigour of 'Empress' and 'Čačanska Rodna' are in agreement with the results reported by Blažek et al. (2004).

Yield efficiency is a significant indicator of productivity, which combines yield and vigour. Values of cumulative yield efficiency (CYE) ranged from 0.46 $\mathrm{kg} / \mathrm{cm}^{2}$ TCSA in 'Požegačáto $1.90 \mathrm{~kg} / \mathrm{cm}^{2}$ TCSA in 'Topper'. The ranking of cultivars based on yield is not identical to that based on CYE. Based on CYE, less vigorous cultivars, such as 'Topper', 'Empress', 'Top' and 'Čačanska Rodna', are much better ranked than based on yield. The opposite is true for some very vigorous cultivars, such as 'President', 'Anna Späth', and 'Tardicotes'. Less vigorous cultivars can be planted at a higher density, and therefore they give higher yields per unit area.

Our results on the yield efficiency of plum cultivars are within the range of values obtained by other researchers (Čmelik et al., 2007; Rozpara and Grzyb, 2007; Markuszewski and Kopytowski, 2013; Głowacka and Rozpara, 2017).

Biennial bearing index (BBI) is a parameter that indicates the variability of yields among years of research. This index was the lowest in 'Nada' (0.06) and the highest in 'Tophit' (0.90). Cultivars with lower BBI values have more stable cropping, which varies less by year. This group includes the cultivars 'Nada', 'Tardicotes', 'Lorida', 'Pozna Plava', 'Zlatka', 'Blufre', and 'Stanley'. In contrast, cultivars with high BBI values are more prone to alternate cropping. This negative trait was most pronounced in 'Tophit', but also in 'Verity', 'Vengerka Pozdnaya', 'Topking', and 'Požegača'. 
Table 2

Trunk cross-sectional area (TCSA), cumulative yield efficiency (CYE), biennial bearing index (BBI), and fruit weight of plum cultivars.

\begin{tabular}{|c|c|c|c|c|}
\hline Cultivar & $\begin{array}{l}\text { TCSA } \\
(2019) \\
\left(\mathrm{cm}^{2}\right) \\
\end{array}$ & $\begin{array}{c}\text { CYE } \\
(2012-2019) \\
\left(\mathrm{kg} / \mathrm{cm}^{2}\right)\end{array}$ & $\begin{array}{c}\text { BBI } \\
(2014-2019)\end{array}$ & $\begin{array}{c}\text { Fruit weight } \\
\text { (2012-2019) } \\
\text { (g) }\end{array}$ \\
\hline Anna Späth & $90.7 \mathrm{ij}$ & 1.07 & 0.32 & $43.8 \mathrm{bc}$ \\
\hline Bluefre & $154.1 \mathrm{ae}$ & 1.00 & 0.20 & $46.1 \mathrm{~b}$ \\
\hline Čačanska Rodna & $93.4 \mathrm{ij}$ & 1.31 & 0.21 & $26.1 \mathrm{i}$ \\
\hline Charadzeyka & $153.0 \mathrm{a}-\mathrm{f}$ & 0.65 & 0.29 & $39.8 \mathrm{~cd}$ \\
\hline Elena & $139.1 \mathrm{a}-\mathrm{g}$ & 1.07 & 0.21 & $25.2 \mathrm{i}$ \\
\hline Empress & $78.0 \mathrm{j}$ & 1.68 & 0.37 & $57.0 \mathrm{a}$ \\
\hline Jojo & $159.4 \mathrm{a}-\mathrm{d}$ & 1.09 & 0.30 & $36.5 \mathrm{de}$ \\
\hline Lorida & $167.0 \mathrm{a}-\mathrm{c}$ & 1.04 & 0.10 & $27.2 \mathrm{i}$ \\
\hline Mildora & 153.4 a-e & 1.11 & 0.36 & $27.1 \mathrm{i}$ \\
\hline Nada & $119.2 \mathrm{~d}-\mathrm{i}$ & 1.37 & 0.06 & $38.6 c-e$ \\
\hline Narach & $129.0 \mathrm{c}-\mathrm{i}$ & 0.92 & 0.35 & $33.0 \mathrm{e}-\mathrm{h}$ \\
\hline Požegača & $178.4 \mathrm{a}$ & 0.46 & 0.41 & $17.9 \mathrm{j}$ \\
\hline Pozna Plava & $136.3 \mathrm{~b}-\mathrm{h}$ & 0.56 & 0.15 & $28.8 \mathrm{~g}-\mathrm{i}$ \\
\hline President & $172.2 \mathrm{ab}$ & 0.85 & 0.31 & $55.8 \mathrm{a}$ \\
\hline Stanley & $106.1 \mathrm{~g}-\mathrm{j}$ & 1.55 & 0.19 & $33.9 \mathrm{e}-\mathrm{g}$ \\
\hline Strinava & $124.2 \mathrm{~d}-\mathrm{i}$ & 1.13 & 0.34 & $28.5 \mathrm{~g}-\mathrm{i}$ \\
\hline Tardicotes & $175.9 \mathrm{ab}$ & 0.84 & 0.09 & $26.2 \mathrm{i}$ \\
\hline Top & $97.5 \mathrm{~h}-\mathrm{j}$ & 1.26 & 0.36 & $26.9 \mathrm{i}$ \\
\hline Topper & $73.1 \mathrm{j}$ & 1.90 & 0.21 & $29.6 \mathrm{f}-\mathrm{i}$ \\
\hline Tophit & $150.0 \mathrm{a}-\mathrm{f}$ & 1.08 & 0.90 & $44.2 \mathrm{bc}$ \\
\hline Topking & $130.6 \mathrm{c}-\mathrm{i}$ & 1.21 & 0.42 & 27.7 hi \\
\hline Vengerka Krupnaya Sladkaya & $157.7 \mathrm{a}-\mathrm{d}$ & 1.01 & 0.43 & $34.6 \mathrm{~d}-\mathrm{f}$ \\
\hline Vengerka Pozdnaya & $112.0 \mathrm{f}-\mathrm{j}$ & 0.73 & 0.47 & $43.1 \mathrm{bc}$ \\
\hline Verity & $145.5 \mathrm{a}-\mathrm{g}$ & 0.92 & 0.49 & $36.8 \mathrm{de}$ \\
\hline Zlatka & $114.2 \mathrm{e}-\mathrm{j}$ & 0.89 & 0.18 & $27.5 \mathrm{hi}$ \\
\hline Average & 132.4 & 1.07 & 0.31 & 34.5 \\
\hline
\end{tabular}

Mean values followed by the same letter within a column do not differ significantly according to Duncan's multiple range test at $\mathrm{P} \leq 0.05$.

Our results on the BBI for cultivar 'Top' are very similar to, and for 'Elena' slightly lower than those given by Čmelik et al. (2007). The BBI values for 'Stanley' and 'Čačanska Rodna' obtained in our study are lower than those obtained by Glišić et al. (2016b). The differences can be explained by different environmental conditions, as well as by more years of testing in our study. However, in both studies, the BBI value was lower in 'Stanley' than in 'Čačanska Rodna'.

The average fruit weight varied from $17.9 \mathrm{~g}$ in 'Požegača' to $57.0 \mathrm{~g}$ in 'Empress'. Compared with the control, fruit weight was statistically significantly higher in seven cultivars, and smaller in nine cultivars. Across years of testing, fruit weight was significantly higher in 2014, 2016 and 2018, compared with 2013 and 2017. This can be explained by higher rainfall amounts during the period of plum fruit development in these three years.

Our results on fruit weight are consistent with previous findings for some cultivars (Blažek and Pišteková, 2009; Minev and Stoyanova, 2012; Markuszewski and Kopytowski, 2013).

\section{Conclusion}

Among the 25 plum cultivars studied in the Belgrade area over the eight-year period significant yield differences were found in both initial and full bearing periods. Compared with the control cultivar ('Stanley'), significantly lower yields in the full bearing period were obtained in eight cultivars, while higher vigour, expressed as trunk cross-sectional area, was found in ten cultivars.
Besides the standard cultivar ('Stanley'), the cultivars 'Blufre', 'Empress', 'Jojo', 'Nada', 'President', and 'Tophit' stand out for their high yields and large fruit size. These cultivars can be recommended for growing in the Belgrade area, as well as other areas with similar environmental conditions.

\section{Acknowledgement}

This work was realised as part of the Project Ref. No. TR 31063 financed by the Ministry of Education, Science and Technological Development of the Republic of Serbia.

\section{References}

Blažek, J., Pišteková, J. (2009). Preliminary evaluation results of new plum cultivars in a dense planting. Horticultural Science, 36(2), 45-54.

Blažek, J., Pištěková, I. (2012). Final evaluation of nine plum cultivars grafted onto two rootstocks in a trial established in 1998 at Holovousy. Horticultural Science, 39(3), 108-115.

Blažek, J., Vávra, R., Pištěková, I. (2004). Orchard performance of new plum cultivars on two rootstocks in a trial at Holovousy in 1998-2003. Horticultural Science, 31(2), 37-43.

Čmelik, Z., Družić, J., Duralija, B., Dugalić, K. (2007). Growth and cropping of plum tree'Felsina', 'Top' and 'Elena'. Voćarstvo, 41, 141-146.

Glišić, I.P., Milošević, T., Glišić, I.S., Ilić, R., Paunović, G., Milošević N. (2016a). Tree vigour and yield of plum grown under high density planting system. Acta Horticulturae, 1139, 131-136. 
Glišić, I., Milošević, T., Ilić, R., Paunović, G. (2016b). Bujnost, prinos i masa ploda šljive ( $P$. domestica L.) u zavisnosti od razmaka sadnje. "XXI savetovanje o biotehnologiji" Zbornik radova, 21 (23), 269-276.

Glowacka, A., Rozpara, E. (2017). Evaluation of several dessert cultivars of plum, new under climatic conditions of Poland. Horticultural Science, 44 (3), 126-132.

Kosina, J. (2004). Orchard performance of two plum cultivars on some clonal rootstocks. Horticultural Science, 31(3), 93-95.

Markuszewski, B., Kopytowski, J. (2013). Evaluation of plum cultivars grafted on 'Wangenheim Prune' rootstock in the northeast of Poland. Folia Horticulturae, 25(2), 101-106.

Meland, M. (2010). Performance of six European plum cultivars on four plum rootstocks growing in a northern climate. Acta Agriculturae Scandinavica Section B - Soil and Plant Science, 60(4), 381-387.

Mészáros, M., Kosin,a J., Laňa,r L., Náměstek J. (2015). Longterm evaluation of growth and yield of Stanley and Cacanska lepotica plum cultivars on selected rootstocks. Horticultural Science, 42(1), 22-28.

Milatović, D. (2019): Šljiva. Naučno voćarsko društvo Srbije, Čačak.

Mileti,ć R., Milošević, N., Karaklajić-Stajić, Ž., Paunović, S.M., Tomić, J., Pešaković, M., Milinković, M. (2019). Influence of dense planting on productivity and fruit quality of dessert plum cultivars. Acta Horticulturae, 1260, 241248.

Minev, I., Stoyanova, T. (2012). Evaluation of plum cultivars in the Troyan region. Voćarstvo, 46, 49-54.

Monselise, S.P., Goldschmidt, E.E. (1982). Alternate bearing in fruit trees. Horticultural Reviews, 4, 129-173.

Ogašanović, D., Ranković, M., Paunović, S., Mitrović, O., Stamenković, S. (2005). Mildora - nova sorta šljive za sušenje. Voćarstvo, 39, 251-256.

Rozpara, E., Grzyb Z.S. (2007). Growth, yield and fruit quality of eighteen plum cultivars grafted on two rootstocks. Acta Horticulturae, 734, 157-161.

Statistical Office of the Republic of Serbia (2020). https://www.stat.gov.rs/en-US/. Access date: 20 March 2020.

Vişanu, F., Botu, I., Baciu, A. (2012). Assessment of production capacity for some plum, myrobalan and sloe cultivars and selections grown in Northern Oltenia. Acta Horticulturae, 968, 75-79.

Vitanova, I., Dimkova, S., Ivanova, D. (2004). Vegetative and reproductive parameters of introduced plum cultivars. Journal of Fruit and Ornamental Plant Research, 12 (spec. ed.), 257-262. 